\title{
POWDER FIXED COMBINATION WITH ANTISEPTIC AND BARRIER PROPERTIES FOR WOUND MANAGEMENT: SAFETY AND EFFICACY ASPECTS
}

\author{
V. Dissette ${ }^{1}$, R. Cassino ${ }^{2}$, L.B. Bondarenko ${ }^{3}$, V.V. Motronenko ${ }^{4 *}$ \\ ${ }^{1}$ Pavia Farmaceutici, Copiano, Italy \\ 2"Sacra Famiglia" Korian Nursing Home, Pieve del Cairo, Italy \\ ${ }^{3}$ Institute of Pharmacology and Toxicology of the National Academy of Medical Sciences of Ukraine, Kyiv, Ukraine \\ ${ }^{4}$ Igor Sikorsky Kyiv Polytechnic Institute, Kyiv, Ukraine \\ *Corresponding author: motronenkovalya@gmail.com
}

Received 15 August 2020; Accepted 12 September 2020

\begin{abstract}
Chronic wounds treatment is a huge problem for the health care of all countries both in the economic aspect (annual costs reach $\$ 9$ billion) and in the time spent by medical personnel to organize adequate long-term monitoring of this category of patients. A variety of etiological, systemic, and local factors may be involved in the pathogenesis of a chronic wound. The situation is aggravated by the fact that with every year the resistance of microorganisms to the widest range of antibiotics is growing. The desire to reduce healthcare costs while improving outcomes drives search for new methods to replace traditional antibiotics. In recent decades, the effectiveness of the use of adsorbents of various nature, biopolymers, cationic surfactants, and various forms of silver for the treatment of wounds has been reassessed. The objective of this review is to summarize the accumulated data of clinical and preclinical studies of substances widely used in medical devices for wound healing: silver, chlorhexidine, hyaluronic acid, and kaolin. The search for alternative medicines for wound healing showed that the most encouraging results regarding multidirectional antimicrobial activity and high safety of use were shown by medicines based on silver, chlorhexidine, hyaluronic acid, and kaolin ions. Combinations of these compounds in one medical device allowed to achieve the optimal effect, which was confirmed by clinical trials of Kadermin (Kadefort).
\end{abstract}

Keywords: wounds treatment; silver ions; chlorhexidine; hyaluronic acid; kaolin.

\section{Introduction}

Chronic wounds treatment is a huge problem for the health care of all countries both in the economic aspect (annual costs reach $\$ 9$ billion) and in the time spent by medical personnel to organize adequate long-term monitoring of this category of patients. A variety of etiological, systemic, and local factors may be involved in the pathogenesis of a chronic wound.

The situation is aggravated by the fact that with every year the resistance of microorganisms to the widest range of antibiotics is growing. Antibiotic-resistant bacteria represent a significant part of the total wound infections [1-3]. Wound colonization with such organisms caused the need for wound aggressive management by a greatly limited choice of antibiotic agents.

The desire to reduce healthcare costs while improving outcomes drives search for new methods to replace traditional antibiotics. In recent decades, the effectiveness of the use of adsorbents of various nature, biopolymers, cationic surfactants, and various forms of silver for the treatment of wounds has been reassessed $[1,3]$.
The objective of this review is to summarize the accumulated data of clinical and preclinical studies of substances widely used in medical devices for wound healing: silver, chlorhexidine, hyaluronic acid, and kaolin.

\section{Efficiency in wound healing}

The antimicrobial action of silver compounds is proportional to the release of bioactive silver ions $\left(\mathrm{Ag}^{+}\right)$and their availability for interaction with bacterial or fungal cell membranes [2]. Metallic and inorganic silver compounds form ions in water solutions, including tissue exudates and other body fluids [2]. The silver ion is biologically active and easily create links with free amino acid residues and such groups in protein molecules, as soon as with free anions and receptors' structures on the cell membranes of mammals and eukaryotes. Susceptibility to bacteria (and possibly fungi) to silver is determined genetically and refers to the levels of absorption of intracellular silver and its interaction with key enzyme systems up to their irreversible denaturation.

Silver ion affects the bacterial cytoplasmic membrane [3]. It binds to groups of electron donors

(C) The Author(s) 2020. Published by Igor Sikorsky Kyiv Polytechnic Institute.

This is an Open Access article distributed under the terms of the license CC BY 4.0 (https://creativecommons.org/licenses/by/4.0/), which permits re-use, distribution, and reproduction in any medium, provided the original work is properly cited. 
in enzymes that are located on the membrane and are involved in cellular replication and energy transduction. By binding to these enzymes, silver causes enzyme inactivation, membrane breakdown, and the release of potassium ions from the bacterial cell, leading to cell death.

Many years of use in medicine allow suggesting that silver (as other noble metals) can potentially be very effective in combating bacterias in wounds [1]. With the increasing use of silver as a topical application in wound care, the interest of investigators to its resistance and toxicity, clinical efficacy, and costeffectiveness, arises [4]. The silver-containing dressings, sprays and other coatings segment of the medical device market is of huge commercial importance. Clinicians need to have maximally full information on silver's antibacterial activity in order that they may provide appropriate treatment for their patients, without any anxieties.

In experiments in virto for three different forms of topical silver, applications were determined bactericidal efficacy against antibiotic-resistant organisms clinical isolates [1]. These silver-contained preparations represent 3 ways of application on wounds: in water solution (silver nitrate), as a component of a cream (silver sulfadiazine), and as a dressing coating (silver-coated dressings).

The decreased number of viable bacterial populations recovered after exposure to silver ions (from test items) was a good comparative measure of these silver applications bactericidal efficacy. Conducted investigations demonstrated that liquid form with silver nitrate, cream with silver sulfadiazine, and silver-coated dressings both can significantly reduce the number of viable bacteria.

But investigators noted that these methods greatly varied in their bactericidal efficacy. The silvercoated dressing was the most efficacious (the most rapid tested bacteria killing and the greatest efficacy against the broadest range of bacteria) and liquid form with silver nitrate - the least efficacious [1]. Thus we can consider silver as a useful prophylactic and therapeutic agent that can prevent wound bacterial colonization.

In other preclinical studies, silver-kaolin topical agent, applied as an aerosol spray, and silver sulphadiazine were evaluated in experiments on male rats [5]. To evaluate the effectiveness of silver-kaolin in treating burn wound sepsis, rats were inoculated on the wound surface with Pseudomonas aeruginosa.

This inoculum resulted in $100 \%$ mortality in untreated rats. Rats treated with silver-kaolin had a mortality rate of $71 \%$, compared to a $9 \%$ mortality rate in rats treated with $1 \%$ silver sulphadiazine.
When silver-kaolin was applied to the wound prior to bacterial inoculation, the mortality rate was reduced to $6 \%$. When wounds were treated with kaolin alone and then inoculated with bacteria, the mortality rate was $50 \%$, indicating that part of the effectiveness of silver-kaolin appeared to be due to a barrier effect. These results indicate that silver-kaolin may be useful for preventive topical antimicrobial therapy of acute burns or after wound debridement or excision.

Interesting results were obtained by another group of researchers in experiments with silver nanoparticles [6]. They supposed that dermal substrate treatment by silver nanoparticles (AgNP) would impart antibacterial properties without contained cells proliferation inhibition.

Their in vitro model included substrate preparation via simple immersion into 0 to $1 \%$ suspension of $\mathrm{AgNP}$ ( 75 or $200 \mathrm{~nm}$ diameter), following rinsing for 20 minutes and sterilization under an ultraviolet C lamp. Injection contained a total of $10^{7}$ human adipose stem cells per cubic centimeter. After 1 hour, $6 \times 10^{5}$ keratinocytes $/ \mathrm{cm}^{2}$ were seeded. Cultivation lasted up to 14 days.

Constructs evaluation was carried out via a metabolic assay (WST-1), and hematoxylin and eosin and immunoperoxidase staining. Determination of bactericidal activity included measurings using a log reduction assay against bacteria that are prevalent in burns.

The use of AgNP did not change constructs metabolic activity in 14 days culture and cells distribution, but antibacterial activity of AgNP $(75 \mathrm{~nm}$ diameter) increased simultaneously with its concentration. Thus, silver nanoparticles inhibited bacterial growth but did not significantly influence cell proliferation. Such an important property makes them very perspective for the development of new types of skin regeneration systems.

The majority of human chronic wounds contain bacterial biofilms that produce proteases and delay the elimination of inflammation [7]. This in turn leads to increased activity of the patient's proteases. Chronic wounds' healing inversely depends on a decrease in proteolytic activities. Therefore, modulation of protease activity can lead to faster healing of chronic wounds.

The silver lactate, octenidine hydrochloride, povidone-iodine, as well as chlorhexidine digluconate ability to inhibit different human proteases and also proteases from Pseudomonas aeruginosa, Staphylococcus aureus, and Serratia marcescens was tested by in vitro zymography [7]. Skin protease rates were investigated by in situ enzymography. All tested 
antimicrobial drugs inhibited both eukaryotic and prokaryotic proteases in vitro. Silver lactate and chlorhexidine digluconate had profound inhibitory effect ex vivo even with partial skin contact in Franz diffusion cells.

Cationic antimicrobials have been widely used in clinical and domestic settings for more than half a century [8]. Retrospective field studies of environments with high levels of these antimicrobials have shown no evidence for resistant microorganisms' strains emerging. Now the clinic has increased the use of antiseptics along with medical devices such as bandages, catheters, and sutures impregnated with biocides. Among these biocides, cations have a clear place. Much of the research on the mechanisms of action of cationic antibacterial drugs was conducted in the 1960s and 1970s and has not been widely revised. Analysis of available publications shows that monoquaternary compounds of ammonium (QAC, cetrimide, benzalkonium chloride), biquaternares and bisbiguanides (chlorhexidine, barkvat), and polymeric biguanides (Vantocil, Cosmocil), although they have similarity in the mechanism of action, differ significantly with cells [8].

Chlorhexidine is active against a wide range of Gram-positive and Gram-negative bacteria and is compatible with a variety of commonly used antibiotics [8]. Despite the fact that the molecule had little systemic activity in mice, it was highly effective against wounds infected with hemolytic Streptococci. Chlorhexidine is widely used in surgical handwashing as an antiseptic and in various topical treatments for early sepsis. It is also widely sold as part of various oral hygiene products as an anti-edematous agent, as well as among topical slow-release agents for the treatment of periodontitis. No resistance to chlorhexidine has been reported, despite its widespread use for almost 50 years in clinical and domestic settings, but small changes (approximately five-fold) in the MIC have been reported.

Hyaluronan is a major carbohydrate component of the extracellular matrix and can be found in the skin, joints, eyes, and most other organs and tissues [9]. It has a simple, repeating disaccharide linear copolymer structure that is fully preserved throughout the great interval of the evolutionary tree, indicating a fundamental biological significance. Among the molecules of the extracellular matrix, it has unique hygroscopic, rheological, and viscoelastic properties.

Hyaluronan binds to many other extracellular matrix molecules, specifically binds to body cells through cell surface receptors, and has a unique method of synthesis in which the molecule is immediately extruded into the extracellular space during formation.

Due to its complex interaction with matrix components and cells, hyaluronan plays a multifaceted role in biology, where both its physicochemical and biological properties are used. These biological roles range from a purely structural function in the extracellular matrix to the regulation of development through the effects of cellular behavior, through the control of tissue macro- and microenvironments, and through direct receptor effects on gene expression [9]. Hyaluronan is believed to play an important biological role in the healing of skin wounds due to its presence in the skin in large quantities. The content of hyaluronan in the skin is temporarily increased in the granulation tissue during wound healing. The general physicochemical and biological properties of hyaluronan can be directly used in modification of various wound healing processes: inflammation, granulation, and reepithelialization in clinic [9].

Deep skin lesions such as burns, injuries, or ulcers are characterized by a massive loss of the dermis [10]. To treat them new dressings based on natural and synthetic polymers were developed during the last decades.

As hyaluronic acid is involved in wound inflammation, granulation, and re-epithelialization processes during its healing, this compound and its derivatives were used for new wound dressings [10]. To increase the poor solubility and rapid destruction of the native polymer, insoluble molecules based on a natural compound are synthesized. Due to their improved structural properties, bandages based on these hyaluronic acid derivatives are a valuable option for the deep burns treatment. Important remedies based on biopolymers with hyaluronic acid are currently available for the treatment of acute wounds such as burns. These substances have been developed to improve dressings that can protect the wound and facilitate healing by combining the properties of hyaluronic acid and improved characteristics of its ester derivatives, providing a long stay in the wound and manufacturability.

Veterinarians often have to deal with injuries to the skin, subcutaneous tissue, and underlying muscles [11]. In special experiments, the use of hyaluronic acid in coatings on open skin wounds in dogs was studied [11].

The course of open skin wounds healing was assessed by reducing the area of wounds and by the two scales used in human medicine. Ten dogs with 
12 open skin wounds were included in the experiments. All wounds were treated using dressings containing hyaluronic acid from the initial admission of the patient to complete reepithelialization. At each clinical examination, the wound area was assessed and determined by rating scales.

When using bandages containing hyaluronic acid, improvements were noted for both wound classification systems. The average number of visits to the clinic to change the bandage was 5 times. The average time for complete wound healing was 34.5 days. The average wound area on days $7,14,21$, and 28 was $90.4 \%, 47.7 \%, 22.4 \%$, and $14.8 \%$ of baseline, respectively (for linear measurements) and $95.5 \%, 54.4 \%$, respectively. $23.10 \%$ and $14.8 \%$ of the original size (when measured using special software).

Thus, a bandage containing hyaluronic acid is an effective treatment for open wounds in dogs.

In other experiments solutions of $0.5 \%$ chlorhexidine acetate and $2 \%$ fusidic acid were compared to evaluate the antibacterial effect when applied to experimental burns of rats previously 24 hours earlier treated with a methicillin-resistant staphylococcal strain [12]. There were significant differences between the fusidic acid group and chlorhexidine acetate group. Although systemic spread of the microorganism in the treatment groups was not observed, it was observed in six animals of the control group.

In the treatment of open wounds, burns and ulcers in addition to bactericidal agents, an important role belongs to the substances which act as protective barriers.

Clays are widely used in protective creams [13] Although such creams differ in composition according to the specific hazard class against which protection is desired (dust, water, grease, sun, etc.), they should be easy to apply and form a continuous, integral and impermeable but flexible film, and should protect the skin by providing it hydration and $\mathrm{pH}$ maintenance.

Kaolin and talc are used in sunscreens to provide a mechanical barrier against dry dust irritants [13]. Sterilized kaolin is incorporated for protective purposes into a water-miscible barrier preparation recommended by the BP Codex Barrier Subcommittee [13]. Clays are also used in sunscreens designed to provide protection from the sun by scattering or absorbing radiant energy. Kaolin and talc are widely used due to their scattering properties.

Such encouraging preclinical results have been confirmed in a large number of clinical trials.

Approximately 250,000 central bloodstream infections are reported in US hospitals each year, and deaths occur in 28,000 cases [14]. The average cost of treatment for each patient is estimated at $\$ 29,156$ and costs $\$ 2.3$ billion annually to the U.S. health care system. In addition, the Medicare and Medicaid Centers have classified central bloodstream infections as "never occurring," which prevents hospitals from receiving reimbursement for treating these infections, further increasing the burden on the health care system. The prevalence of central bloodstream infections underscores the importance of preventing them. To combat them, bandages have been developed to prevent blood contamination [14].

Bandages impregnated with chlorhexidine gluconate (HCG) and bandages with silver alginate are the two main classes of antimicrobial bandages [14]. HCG is a common antiseptic that is used in many medical protocols because of its strong antibiotic action on bacteria. Silver-containing alginate dressings have antibiotic properties due to the release of silver ions, which are well known for antiseptic applications since ancient times. DeRoyal has developed a new wound dressing called Algidex AGR, which incorporates maltodextrin into a silver-containing alginate matrix.

The antibacterial mechanisms of action, the results of the comparison of the potential of antibacterial resistance and the comparison of the safety of HCG and silver for use in humans are summarized to highlight the benefits of the Algidex AGR IV patch for catheter patients. The strengths and weaknesses of chlorhexidine and ionic silver as antiseptics for the prevention of central bloodstream infections have been identified and carefully studied [14].

Chlorhexidine is a proven antiseptic that has a rapid increase in clinical utilization due to the emergence of antibiotic-resistant bacteria [14]. HCG kills most bacteria in 20 seconds and has a long-lasting effect. Adverse skins reactions are the most common complication associated with HCG and have been consistently attributed to repeated and persistent exposure to HCG-impregnated medications. These problems with the clinical use of HCG have led researchers to explore new antiseptic methods and tools that help maintain a safe and clean clinical environment, especially in maintaining a clean environment around the catheters located in the body.

Ionic silver as an antiseptic has survived the revival of modern medicine due to its effective multifaceted antimicrobial mechanism of action and safety in humans [14]. The potential of bacteria to develop effective resistance to silver is considered to be minimal, as no significant mechanism of resistance has been identified, despite the effects of silver on bacteria over 4 million years and more than a thousand years of human antiseptic use. 
Both chlorhexidine and silver products, such as the Algidex AGR IV patch, are present in clinical antisepsis protocols; however, the benefits and risks need to be considered [14]. At the clinic, the goal is to prevent nosocomial infection without compromising the patient's other risks. Widespread use of HCG products threatens to increase bacterial resistance to HCG, similar to the rapid rise in bacterial resistance to antibiotics. Medical clinics must adopt a multifaceted antiseptic protocol that includes more than one antiseptic to effectively fight bacteria with antibiotic resistance. In addition, there is a growing tendency in patients to develop sensitivity or allergy to HCG from prolonged or repeated exposure to the chemical. Reducing patients' HCG allergies should be a priority in medical centers that use HCG exclusively for antisepsis.

Although silver-based technologies have been successfully used in a variety of devices and pharmaceuticals, such as chronic hemodialysis catheters, endotracheal tubes, urinary catheters, and wound care products, duly received evidences for the efficacy of silver as bactericidal substance in medical devices are limited, especially for urinary and vascularcatheters [3].

In the Guidelines for Urinary Tract Infection Related to the CDC Catheter (2009), evidence of the efficacy of silver when used in urinary catheters was referred to as "low quality," and the use of these catheters was recommended 1B [3]. In the CDC Guidelines for the Prevention of Intravascular Catheter Infections (2011), vascular platinum/silver catheters were reported to have mixed data (one study showed a decrease in catheter colonization frequency and CRBSI, another study found no difference in catheter colonization), which did not provide recommendations for its use to prevent intravascular catheter infection.

A clinical trial examining the use of silvercoated endotracheal tubes did not show a reduction in microbial colonization without a significant reduction in morbidity during prolonged intubation, a reduction in hospital stay and side effects frequency and severity [3]. Silver has only been shown to be effective in short-term in vitro studies, but its efficacy in clinical trials is questionable.

In limited clinical trials the effectiveness of the antiseptic action of the spray powder with silver ion was evaluated both in the treatment and in the prevention of bacterial colonization in diabetic foot injuries [15].

The study enrolled 36 patients, 14 - with infected lesions and $22-$ with pure lesions. The treatment procedure involved cleaning the lesion with saline and subsequent application of antiseptic spray with ionic silver as the main means of therapy, and non-stick gauze without the active ingredient was used as a secondary dressing. The dressing was changed every 48 hours.

The test results showed that all patients with infected lesions improved and cured, and only 1 patient with pure lesions had a recurrence after 60 days. It is necessary to emphasize the short recovery time in both groups (16.7 and 15.2 days, respectively). Thus, antiseptic spray with ionic silver demonstrated efficacy for the treatment of diabetic foot injuries, both infected and purified [15].

Modern treatment of partial thickness burns should be conducted on the paradigm of less frequent dressings, which allows for unimpeded reepithelialization of the burn wound.

In special clinical trials investigators compared Mepilex $\mathrm{Ag}^{+}$, a silver-impregnated polymer, and $\mathrm{Su}-$ prathel, a polymer of DL-lactic acid in the outpatient treatment of partial-thickness burns in children and adult patients [16].

Patients were included in a randomized, controlled, prospective clinical trial. Re-epithelialization time, wound pain, bandage discomfort, and treatment costs were monitored. Objective characteristics of the scar (elasticity, transepidermal water loss, hydration, and pigmentation) and subjective assessments (scale of assessment of the patient's and observer's scar) were measured 1 month after the burn. Data were presented as mean \pm SEM, and significance was taken at $p<0.05$.

Sixty-two patients were included in the trial (Suprathel $n=32$; Mepilex $\mathrm{Ag}^{+} n=30$ ); age, sex, and size of care were comparable between groups [16]. Reepithelialization time did not differ between groups (12 days; $P=0.75$ ). The pain rating was significantly lowered just in the first 5 days after the appearance of a burn in the Suprathel group in all patients $(P=0.03)$ and the pediatric subgroup $(P<0.001)$. The viscolesticity of the burnt skin was increased compared to unaffected skin of the Mepilex $\mathrm{Ag}^{+}$group 1 month after the burn. Suprathel treated patients demonstrated better overall scar quality (S: 2 ; M: $4.5 ; P<0.001$ ). Mepilex $\mathrm{Ag}^{+}$treatment cost per square centimeter for Mepilex $\mathrm{Ag}^{+}$was significantly lower than that of Suprathel.

Obtained results demonstrated that both dressings are appropriate and effective for the outpatient treatment of minor burns of medium partial thickness [16].

Extensive studies of all abovementioned compounds for wound healing have been conducted by Pavia Farmaceutici [17]. 
Kaolin and other types of clay are widely used as rheological modifiers, stabilizers and carriers in products for medical use; in particular kaolin is used in protective products due to its barrier agent properties. Examples of different types of kaolin application are given, starting from the cosmetic industry, where natural clays have been used since ancient times as adsorbent and protective coatings, and up to the developments of recent years - the use of active pharmaceutical ingredients as a carrier. In clinical a trial was noted the effectiveness of kaolin in the formation of a protective barrier on skin lesions when using the medical device "Argostop," which is a spray of kaolin and silver [17].

Also in clinical trial was noted the effectiveness of the use of sodium hyaluronate in "DM" sprays for skin lesions [17]. Hyaluronic acid as a polymer of natural origin is able to coordinate a large number of water molecules around its structure and provide the skin with long-term hydration. Given its polymeric nature, hyaluronic acid is able to create threedimensional structures with film properties. Efficacy of the use of hyaluronic acid in surface coatings for the treatment of skin lesions has been reported [17]. The improvement of diabetic wound healing processes (including epithelial migration and differentiation) treated with hyaluronic acid is highlighted [17].

In general overview of scientific and clinical results on the use of cationic surfactants in clinical settings for the treatment of wounds due to their antiseptic properties different mechanisms of action of various chemical species were identified [17]. Were established and explained different mechanisms of action of silver and its compounds and their toxicological profile depending on the method of application. In particular, it should be stressed, that based on the available data, transcutaneous absorption of silver particles is extremely small. Three different ways of using silver in the treatment of ulcers are analyzed and the results of testing its antimicrobial effect against antibiotic-resistant bacterial strains are presented. Silver was effective in all three forms used (liquid, cream, coating) to limit the bacterial growth of the studied strains.

In the results of the Cochrane report on the effectiveness of silver-based drugs in the treatment of diabetic foot; in particular, the ability of silver to reduce the number of colonies of bacteria involved in the infectious process is emphasized [17].

The results of the report of a multi-center test conducted in Italy to study the effectiveness of amino acids in tissue repair are also presented [17].
Clinical trial results showing the effectiveness of medical materials based on sodium hyaluronate are presented [17].

Generalized analysis of available scientific data in the collected scientific documentation demonstrated that the raw materials used for the formulations of medical devices of the SKIN REPAIR line, in particular in the components of the SCXPOWDER complex (silicon dioxide functionalized with silver ions and chlorexidine) widely demonstrate their effectiveness in the treatment of skin lesions [17].

Documentation confirming the use of hyaluronic acid indicates its presence in medical devices similar in shape and purpose on the market [17]. Hyaluronic acid is widely used in cosmetology as a moisturizing and protective agent, as well as in medicine - as a carrier in drug delivery systems to the site of action in the ophthalmic field. The use of its various pharmaceutical forms: powder, mousse and foam - largely depends on the local situation, which is determined by the type of tissue and the quantity/quality of exudate. Especially indicated is the treatment of the skin around the lesion (with uniform application until complete absorption) before applying the drug to the lesion, both for prophylactic antiseptic action and for the ability to restore microdamage to the area around the lesion.

\section{Safety of substances used in medical devices}

It is obvious that no, even the highest efficiency, can be the only criterion for creating medical products for the treatment of wounds, burns and ulcers. The safety of the agents used in this case is especially important, since along with local exposure, there is a likelihood of these compounds entering the bloodstream and their systemic effect on the body.

Preclinical in vitro and in vivo experiments demonstrated that proteins, carbohydrates and lipids could easily bind to silver ions present in clinical use, inactivating its antimicrobial action [3]. There is a small risk of sensitivity to silver or local discoloration of the skin [3].

Special investigations of silver toxicological profile were carried out [18].

Silver is widely used in dressings for wounds and medical devices as antibiotic with a broad spectrum of action. Metallic silver and most inorganic silver compounds ionize moisture, liquids and secretions with biologically active $\mathrm{Ag}^{+}$releasing. The $\mathrm{Ag}^{+}$ 
is absorbed from diet and drinking water, by inhalation and internal parenteral administration into the systemic circulation. Through the skin its absorption is low [18].

$\mathrm{Ag}^{+}$is highly bound to metallothionein, albumin and macroglobulins and is metabolized in all tissues except the brain and central nervous system [18]. Precipitates of silver sulfide or silver selenide bound lysosomally in soft tissues are inert and cannot be associated with irreversible toxic change.

Argyria and argyrosis are the main consequences of severe deposition of insoluble silver deposits in the dermis and cornea/conjunctiva. Although these changes may be profound and persistent, they cannot cause any pathological lesions of any tissue [18].

There are several theories about mechanisms of absorption and metabolism of silver in the human body, the mechanisms of argyria and argyrosis and excretion of silver-protein complexes in bile and urine [18]. The minimum levels of silver in the blood corresponding to the early signs of argyria or argyrosis are not known. There is an allergy to silver, but the extent of the problem is unknown. Reference values of silver exposure are not definitively defined yet.

The health risks caused by $\mathrm{Ag}^{+}$systemic absorption are low [18]. Argyria and argyrosis are the main observed changes associated with prolonged exposure to or inhalation of metallic silver compounds or silver ions, but they are not life-threatening and are not associated with irreversible tissue damage. Thus, it is debatable to classify these conditions as "toxic changes," but it should be emphasized that severe prolonged argyria and argirosis resulting from exposure to silver in occupational activities without protective equipment or unregulated consumption or inhalation of colloidal silver preparations may be deep and cause serious psychological and personal problems, and should not be dismissed as inappropriate observations.

There is no conclusive evidence that silver causes morphological damage to neurological tissues [18]. Clinical experience has shown that temporary changes in the hepatic and renal enzyme systems in patients receiving high levels of silver in the clinic or from the environment are minimally toxic. There is currently no strong evidence that silver that accumulates in bone significantly affects Ca-mediated events in the heart, skin, and other tissues, or cause osteoporosis, but further clinical studies are needed.

On the other hand, there is compelling evidence that silver, like most other xenobiotic metals, can cause delayed contact hypersensitivity reactions and allergies in susceptible people, and this should be considered a potential toxic hazard, although the degree of risk is unknown [18].

Animal experiments do not suggest anything about the humans' possible risks associated with exposure to silver or sensitivity to argyria, but some give useful information on metal metabolism in the cell and the role of silver-binding proteins and carrier proteins in cytoprotection and metabolism [18].

In vitro toxicity studies with silver affecting fibroblasts, keratinocytes or other cell lines are minimally relevant to in vivo experiments using recognized animal models, but they are useful to confirm the absence of mutagenicity or carcinogenic changes in silver.

Regulatory authorities have established benchmarks and restrictions on the effects of metallic silver and soluble silver compounds on occupational safety, drinking water, medical devices, wound dressings and consumer goods taking into account published data on argyria and/or argyrosis [18].

Only one patient showed profound argyria due to 2 years of exposure to silver acetate, associated with a total accumulation in the body of $6.4 \mathrm{~g}$ of silver, much of which was deposited in the skin $71.7 \mu \mathrm{g} \cdot \mathrm{g}^{-1}$ [18]. Despite the fact that the skin concentrations of silver were 8000 times higher than normal control values, the patient remained in normal health.

In another case, argyria in a burn patient receiving a silver-bandaging wound was associated with a blood silver level of $107 \mu \mathrm{g} \cdot \mathrm{kg}^{-1}$ and a urine silver level of $28 \mu \mathrm{g} \cdot \mathrm{kg}^{-1}$, but there were no other changes [18].

Other studies claim that the total concentration of silver in the body of 4-5 g can lead to a clinical picture of argyria [18]. 365 cases of argyria were reported to the US Food and Drug Administration. To achieve the state of argyria is required a total load on the body of $3.8 \mathrm{~g}$ of elemental silver. It is emphasized that the estimates of silver in the body in these older studies are much less accurate than those available today, using thermoatomic absorption spectrophotometry or mass spectrometry with a sensitivity of $1 \mu \mathrm{g} \cdot \mathrm{L}^{-1}$. Today, there are few opportunities to study silver consumption as a cause of argiric change, as silver compounds are not available for oral or enteral administration (except for silver acetate in anti-smoking agents) in many countries.

Current limits of exposure to metallic compounds of silver and silver ions $0.01 \mathrm{mg} / \mathrm{m}^{3}$ in air (silver content in drinking water $0.10 \mathrm{mg} \cdot \mathrm{L}^{-1}$ ) set by the National Institute of Occupational Safety and the American Conference of Governmental Industrial 
Hygienists in the field of environment indicate that people are unlikely to be exposed to enough silver in food, drinking water, the workplace, or in therapeutic agents to trigger argyria symptoms [18]. The amount of $\mathrm{Ag}^{+}$released from catheters, textiles, and wound dressings that use silver for permitted antibiotic purposes is negligible and have no toxicological significance except as a cause of allergy.

However, the uncontrolled intake or inhalation of colloidal silver preparations (with indeterminate concentrations of ionizing silver) for the treatment of infectious and non-infectious conditions still poses a real risk for argyria and argyrosis and related psychological problems.

Silver should not be considered as an accumulative poison [18]. Only in cases of chronic systemic silver overload, when the excretory mechanisms are supersaturated, silver is deposited in an inert way in lysosomal or intercellular areas not associated with tissue damage. In these situations, selenium is the main protective factor in the deposition of silver in the inert form of silver selenide. Although some of it can be used in the lysosomes of macrophages, these deposits are essentially long-lived or permanent. The available knowledge suggests that argiremias $<3 \mu \mathrm{g} \times \mathrm{L}^{-1}$ are common in normal healthy people, and that elevated levels are observed in people exposed to the metal without appropriate protective measures (face masks, etc.).

The toxicity profile for skin irritation and hypersensitivity to both polymeric biguanides and biguanides (including chlorhexidine) is excellent at conventional levels of use [8].

Special clinical trials compared the safety of chlorhexidine and silver for use in humans [14]. The strengths and weaknesses of chlorhexidine and ionic silver as antiseptics for the prevention of central bloodstream infections have been identified and carefully studied.

Chlorhexidine can be used from the second week of life of the newborn according to the new instructions of the European Medicines Agency (EMA) [14]. The British Medicines and Drug Administration (MHRA) also states that chlorhexidine should be used with caution due to the possibility of skin irritation or burns in newborns, especially those born before 32 weeks of gestation, as well as in newborns during the first two weeks of life [14].

Chlorhexidine safety problems arise from the documented increase in bacterial resistance and the prevalence of sensitivity to chlorhexidine and allergies, due to the over-dependence and indiscriminate use of chlorhexidine in medical clinics around the world. Adverse skin reactions are the most common complication associated with chlorhexidine and have been consistently attributed to repeated and persistent exposure to chlorhexidine - impregnated medications [14].

Ionic silver as an antiseptic has survived the revival of modern medicine due to its effective multifaceted antimicrobial mechanism of action and safety in humans. Allergy to silver is very rare and often requires a large amount of absorption of silver before a person becomes sensitive to silver [14]. In addition, silver dressings for wounds did not cause severe skin ulcers, as was the case for chlorhexidineimpregnated dressings [14].

Although bacterial mechanisms of resistance to silver exist, studies have shown that these mechanisms are rare, not easily tolerated, and do not necessarily provide effective resistance to silver ions [14]. The potential of bacteria to develop effective resistance to silver is considered to be minimal, as no significant mechanism of resistance has been identified.

Another researchers' data contained experimental proof of the absence of toxicity of silver during tissue growth and the presence of its antibacterial effect [17]. Particular attention in these experiments was paid to the ionic form of the metal.

Clinical experience to date suggests that medical devices with hyaluronic acid are safe and useful for the treatment of wounds [10].

Based on the collected documentation, intended use and risk management analysis, medicines based on silver, chlorhexidine, hyaluronic acid and kaolin meet the necessary requirements for performance and safety; based on the assessments expressed in the risk analysis, the products are safe according to current scientific data [17]. In addition, based on the accumulated direct and indirect experience, the use of such tools is effective even with a single daily use in cases of minor injuries.

No adverse reactions, intolerances or allergies have been reported since the sale of medical devices, based on silver, chlorhexidine, hyaluronic acid and kaolin [17]. These products can be used for a long time, depending on the nature of the lesion.

\section{New compositions for wound healing}

Given such encouraging results regarding multidirectional antimicrobial activity and high safety of silver, chlorhexidine, hyaluronic acid and kaolin use as agents for wound healing it was logical to try to combine these compounds in one medical device to achieve the optimal effect. And such attempts have been made. 
In particular, as evidenced by trials on clinical evaluation of Kadermin antimicrobial spray in pediatric practice on the basis of the Department of Pediatric Surgery of the Department of Pediatric Surgery and Intensive Care of the Department of Surgery of the Medical Center in Ljubljana, antimicrobial spray Kadermin (which consists of silver ions, chlorhexidine, hyaluronic acid and kaolin) demonstrated profound effectiveness and safety in pediatric practice [19]. International clinical trials have shown that the antimicrobial spray is also effective for minor burns, eczema, sunburn, bedsores, ulcers, diabetic foot, athlete's foot, and macerated skin caused by secretions. It is neither flammable nor greasy.

The spray was applied to the cleansed affected area of skin in a thin layer [19]. Three children with inflamed and macerated skin were observed. Researchers used Kadermin antimicrobial spray, which was applied to a clean and washed skin surface several times a day [19]. The white powder, which remained on the surface of the skin as a protective film, protected healthy skin and helped macerated skin to recover. The spray has been shown to be a good remedy for macerated skin and fungal rashes, as the skin breathes under a spray layer. The improvement came quickly. However, more children with similar problems will be needed to confirm good results.

Possibilities of treatment of trophic ulcers in patients with decompensated forms of chronic venous insufficiency of the lower extremities using Kadefort spray (SCX-powder: silicon dioxide functionlized with silver ions and chlorhexidine) were investigated at the Department of Main Vascular Surgery of the O.O. Shalimov National Institute of Surgery and Transplantology of the National Academy of Medical Sciences of Ukraine [20].

The problem of decompensated forms of chronic venous insufficiency (CVI) of the lower extremities is relevant in Ukraine due to its prevalence, especially among the working population. The reason for the growth of these patients number is late detection and inadequate treatment in non-specialized medical institutions. Treatment of trophic ulcers caused by decompensation of venous blood flow to the extremities is complex and not always effective, which encourages the search for new methods in the treatment of this category of patients [20].

A comparative analysis of treatment of $60 \mathrm{pa}$ tients with venous trophic ulcers aged 39 to 74 years was carried out during 2018-2019 [20].
The cause of CVI was postthrombophlebitic syndrom. The diagnosis was based on clinical data, ultrasound Doppler, X-ray-contrast phlebography. The area of trophic ulcers in patients, including 43 women and 17 men, ranged from 20 to $48 \mathrm{~cm}^{2}$. Patients were divided into 3 groups of 20 patients. In three groups, patients received baseline conconservative therapy with phlebo- and lymphotonics, compressure therapy, physiotherapy treatment. Local treatment of ulcers differed: patients of the $1^{\text {st }}$ group received bandages with Kadefort once per day for 14 days, patients of the $2^{\text {nd }}$ group - dressings with tyrosure once a day for 14 days, patients of the $3^{\text {rd }}$ group - dressings with betadine once a day for 14 days.

The most common localization of trophic ulcers at CVI was observed on a medial surface the lower third of the shin, which was undeniable, proved during observations. Trophic ulcers on the medial surface of the lower leg and with sitting on the upper third of the shin took place in $38(63.3 \%)$ patients. On the lateral surface of the lower third of the leg trophic ulcers observed in $16(26.7 \%)$ patients and in the lateral area the middle third of the leg - only in $6(10.0 \%)$.

Before starting treatment, patients were determined to the average area of the trophic ulcer. Treated with antiseptic polyethylene film was applied to the surface of the ulcer and outlined its contours. The resulting images of trophic ulcer were applied to a millimeter sheet paper and the average area of ulcers was determined (in $\mathrm{cm}^{2}, \mathrm{~mm}^{2}$ ).

Microbiological studies have shown that trophic ulcers are characterized by high microbial contamination, with the most common pathogenic Staphylococcus spp. - in 35 (58.3\%) patients, Streptococcus spp. in 14 (23.3\%) patients, Proteus spp. - in 12 (20.0\%) patients, Escherichia coli - in 8 (13.3\%).

Most often, patients had the pain directly in the area of the ulcer, especially often - when walking, the feeling of "creeping ants" in the affected area of skin, itching around the ulcer, sleep disturbances, inflammation in the area of the ulcer and surrounding tissues.

During Kadefort spray clinical trials patients were followed for 14 days. Satisfactory and good results - reduction of the ulcer area by more than $50 \%$ or its complete healing - were observed in 19 (95\%) patients of group 1, in $12(60 \%)$ patients of group 2 and in $8(40 \%)$ patients of the $3^{\text {rd }}$ group. In addition, the healing of ulcers in the $1^{\text {st }}$ group was faster on average by 4 days. 
Thus, the use in the complex treatment of patients with decompensated forms of chronic venous insufficiency of the lower extremities spray Kadefort can reduce the healing time of trophic ulcers, ensure the absence of infection in the wound, prevent the fungal infection, improve granulation growth, which is associated with a positive complex effect on trophic ulcers. There have been no reports of product adverse effects. The data on the use of Kadefort spray allow considering it as the medical device of choice for the local treatment of patients with trophic ulcers in decompensated forms of chronic venous insufficiency of the lower extremities.

\section{Conclusions}

Thus, growing resistance of microorganisms to the widest range of antibiotics caused increasing of researchers' interest to alternative medicines for wounds treatment. Among them encouraging results regarding multidirectional antimicrobial activity and high safety of use demonstrated medical devices on the base of silver ions, chlorhexidine, hyaluronic acid and kaolin. Combinations of these compounds in one medical device allowed to achieve the optimal effect, which was confirmed by clinical trials of Kadermin (Kadefort).

\section{References}

[1] Wright JB, Lam K, Burrell RE. Wound management in an era of increasing bacterial antibiotic resistance: a role for topical silver treatment. Am J Infect Control. 1998;26(6):572-7. DOI: 10.1053/ic.1998.v26.a93527

[2] Lansdown ABG. Silver in health care: Antimicrobial effects and safety in use. Curr Probl Dermatol. 2006;33:17-34. DOI: $10.1159 / 000093928$

[3] Raymond JT. Is silver the ultimate antimicrobial bullet? Antibiotics (Basel). 2018;7(4):112. DOI: 10.3390/antibiotics7040112

[4] Cutting K, White R, Edmonds M. The safety and efficacy of dressings with silver - addressing clinical concerns. Int Wound J. 2007;4(2):177-84. DOI: 10.1111/j.1742-481x.2007.00338.x

[5] Linares HA, Fader RC. Evaluation of topical therapy with silver-kaolin (Argostop) in an experimental model of burn wound sepsis. Burns Incl Therm Inj. 1987;13(4):281-5. DOI: 10.1016/0305-4179(87)90046-5

[6] Zieger MA, Ochoa M, Rahimi R, Campana G, Tholpady S, Ziaie B, et al. Skin regeneration using dermal substrates that contain autologous cells and silver nanoparticles to promote antibacterial activity: in vitro studies. Mil Med. 2017;182(S1):376-82. DOI: $10.7205 /$ milmed-d-16-00133

[7] Pavluk V, Sojka M, Mazúrová M, Velebný V. Dual role of iodine, silver, chlorhexidine and octenidine as antimicrobial and antiprotease agents. PLoS ONE. 2019;14(1):e0211055. DOI: 10.1371/journal.pone.0211055

[8] Gilbert P, Moore LE. Cationic antiseptics: diversity of action under a common epithet. J Appl Microbiol. 2005;99:703-15. DOI: $10.1111 /$ j. $1365-2672.2005 .02664 . x$

[9] Chen WYJ, Abatangelo G. Functions of hyaluronan in wound repair. Wound Rep Reg. 1999;7:79-89. DOI: $10.1046 /$ j.1524-475x.1999.00079.x

[10] Longinotti C. The use of hyaluronic acid based dressings to treat burns: A review. Burns Trauma. 2014;2(4):1-6. DOI: $10.4103 / 2321-3868.142398$

[11] Ferrari R, Boracchi P, Romussi S, Ravasio G, Stefanello D. Application of hyaluronic acid in the healing of non-experimental open wounds: A pilot study on 12 wounds in 10 client-owned dogs. Vet World. 2015;8(10):1247-59. DOI: $10.14202 /$ vetworld.2015.1247-1259

[12] Ulkür E, Oncul O, Karagoz H, Yeniz H. Comparison of silver-coated dressing (Acticoat (TM)), chlorhexidine acetate $0.5 \%$ (Bactigrass $((\mathrm{R})))$, and fusidic acid $2 \%($ Fucidin $((\mathrm{R})))$ for topical antibacterial effect in methicillin-resistant Staphylococcicontaminated, full-skin thickness rat burn wounds. Burns. 2005;31(7):874-7. DOI: 10.1016/j.burns.2005.05.002

[13] Viseras C, Aguzzi C, Cerezo P, Lopez-Galindo A. Uses of clay minerals in semisolid health care and therapeutic products. Appl Clay Sci. 2007;36:37-50. DOI: 10.1016/j.clay.2006.07.006

[14] Antimicrobial IV Dressings: Algidex AG $^{\circledR}$ versus Chlorhexidine Gluconate [Internet]. Deroyal.com. 2020 [cited 2020 Aug 8]. Available from: https:/www.deroyal.com/docs/default-source/product-literature/0-2426-algidex-vs-chlorhexidine-gluconatewhite-paper-sept-2017.pdf?sfvrsn=7c5100b6_8

[15] Cassino R, Ippolito AM. L'uso dell'argento ionico nella cura del piede diabetico:prevenzione e trattamento dell'infezione. Acta Biomed. 2013;84:3-9.

[16] Hundeshagen G, Collins VN, Wurzer P, Sherman W, Voigt CD, Cambiaso-Daniel J, et al. A prospective, randomized, controlled trial comparing the outpatient treatment of pediatric and adult partial-thickness burns with suprathel or mepilex Ag. J Burn Care Res. 2018;39(2):261-7. DOI: 10.1097/bcr.0000000000000584

[17] Morrison L, Zembower TD. Antimicrobial resistance. Gastrointest Endosc Clin N Am. 2020;30(4):619-35. DOI: $10.1016 /$ j.giec.2020.06.004 
[18] Lansdown ABG. A pharmacological and toxicological profile of silver as an antimicrobial agent in medical devices. Adv Pharmacol Pharm Sci. 2010;2010:16. DOI: 10.1155/2010/910686

[19] Mademli A. Osetreni inkontinenĉni dermatitidy u imobilnich pacientů. Lèĉbaran (CWMA). 2019:3:20-1.

[20] Nikulnikov PI, Liksunov OV, Ratushniuk AV, Bicher AH. Possibilities of trophic ulcers treatment in patients with decompensated forms of chronic venous insufficiency of the lower extremities using Kadefort ${ }^{\mathrm{TM}}$ spray. Zdorovia Ukrainy. 2019;1:1-2.

В. Діссетте, Р. Кассіно, Л.Б. Бондаренко, В.В. Мотроненко

\section{ПОРОШКОПОДІБНА КОМБНАЦІЯ 3 АНТИСЕПТИЧНИМИ ТА БАР'ЄРНИМИ ВЛАСТИВОСТЯМИ ДЛЯ ЛІКУВАННЯ РАН: АСПЕКТИ БЕЗПЕКИ Й ЕФЕКТИВНОСТІ}

Лікування хронічних ран є величезною проблемою для охорони здоров'я всіх країн як в економічному аспекті (щорічні витрати сягають 9 млрд дол.), так і з точки зору часу, витраченого медичним персоналом на організацію адекватного тривалого моніторингу цієї категорії пацієнтів. У патогенезі хронічної рани можуть бути задіяні різноманітні етіологічні, системні та місцеві фрактори. Ситуацію погіршує той факт, що з кожним роком резистентність мікроорганізмів до найширшого кола антибіотиків зростає. Прагнення скоротити витрати на охорону здоров'я при одночасному поліпшенні результатів лікування зумовлює пошук нових методів заміни традиційних антибіотиків. В останні десятиліття доведена значна ефективність використання адсорбентів різної природи, біополімерів, катіонних поверхнево-активних речовин і різних форм срібла для лікування ран. Мета цього огляду - узагальнити накопичені дані клінічних і доклінічних досліджень речовин, які широко використовуються в медичних засобах: срібла, хлоргексидину, гіалуронової кислоти та каоліну. Пошук альтернативних лікарських засобів для загоєння ран показав, що найбільш обнадійливі результати щодо різноспрямованої антимікробної активності та високої безпеки використання показали медичні засоби на основі іонів срібла, хлоргексидину, гіалуронової кислоти та каоліну. Поєднання цих сполук в одному медичному засобі дало можливість досягти оптимального ефекту, що було підтверджено клінічними випробуваннями Kadermin i Kadefort.

Ключові слова: лікування ран; іони срібла; хлоргексидин; гіалуронова кислота; каолін.

\section{В. Диссетте, Р. Кассино, Л.Б. Бондаренко, В.В. Мотроненко}

\section{ФИКСИРОВАННАЯ ПОРОШКОВАЯ КОМБИНАЦИЯ С АНТИСЕПТИЧЕСКИМИ И БАРЬЕРНЫМИ СВОЙСТВАМИ ДЛЯ ЛЕЧЕНИЯ РАН: АСПЕКТЫ БЕЗОПАСНОСТИ И ЭФФЕКТИВНОСТИ}

Лечение хронических ран является огромной проблемой для здравоохранения всех стран как в экономическом аспекте (ежегодные расходы достигают 9 млрд долл.), так и с точки зрения времени, затраченного медицинским персоналом на организацию адекватного длительного мониторинга этой категории пациентов. В патогенез хронической раны могут быть вовлечены различные этиологические, системные и местные фракторы. Ситуацию усугубляет тот факт, что с каждым годом резистентность микроорганизмов к самому широкому кругу антибиотиков возрастает. Стремление сократить расходы на здравоохранение при одновременном улучшении результатов лечения обусловливает поиск новых методов замены традиционных антибиотиков. В последние десятилетия доказана значительная эффективность использования адсорбентов различной природы, биополимеров, катионных поверхностно-активных веществ и различных форм серебра для лечения ран. Цель этого обзора - обобщить накопленные данные клинических и доклинических исследований веществ, которые широко используются в медицинских средствах: серебра, хлоргексидина, гиалуроновой кислоты и каолина. Поиск альтернативных лекарственных средств для заживления ран показал, что наиболее обнадеживающие результаты относительно разнонаправленной антимикробной активности и высокой безопасности использования показали медицинские средства на основе ионов серебра, хлоргексидина, гиалуроновой кислоты и каолина. Сочетание этих соединений в одном медицинском средстве позволило достичь оптимального эффекта, что было подтверждено клиническими испытаниями Kadermin и Kadefort.

Ключевые слова: лечение ран; ионы серебра; хлоргексидин; гиалуроновая кислота; каолин. 